The Polish Journal of the Arts and Culture. New Series 5

(1/2017): 7-29 [ARTYKUE]

DOI: $10.4467 / 24506249$ PJ.17.001.6808

\title{
Polityka językowa oraz kulturalna Islamskiej Republiki Iranu w Afganistanie i Tadżykistanie
}

\author{
Jakub G. GAJDA
}

\begin{abstract}
Streszczenie
Afganistan, Iran i Tadżykistan dzielą z sobą wiele wieków wspólnej historii, choć współcześnie stanowią trzy odrębne tożsamości państwowe. Korzenie ich państwowości związane są z irańską kulturą polityczną imperium Achemenidów, zaś źródeł ich tożsamości narodowej należy się dopatrywać w irańskiej religii - zaratusztrianizmie, perskiej literaturze i poezji. Również współczesne języki urzędowe trzech państw pozostają spokrewnione. Dążący do regionalnej potęgi Iran stara się wykorzystać pokrewieństwo w relacjach z Afganistanem i Tadżykistanem. Aspekt ten wydaje się nie mniej istotny od czynnika religijnego - szyizmu, który dominuje we wszystkich sferach życia w Iranie po 1979 roku. W procesie integracji istotna jest rola święta Nouruz. Irański nowy rok stał się okazją do spotkań liderów państw objętych projektem tak zwanej Unii Państw Perskojęzycznych. Wspólne dziedzictwo i jego wykorzystanie przez Iran pozostaje tematem wartym poruszenia w dyskursie o współczesnym świecie irańskim. Artykuł w sposób przekrojowy skupia się na okresie 1979-2014.
\end{abstract}

Słowa kluczowe: Iran, Afganistan, Tadżykistan, polityka, kultura, jezzyk

Jakub G. GAJDA absolwent iranistyki Uniwersytetu Jagiellońskiego, doktorant IHSD na Uniwersytecie Łódzkim, ekspert ds. Iranu, Afganistanu, Bliskiego Wschodu i Azji Centralnej Fundacji Amicus Europae oraz Fundacji Kazimierza Pułaskiego.

E-MAIL: jakubgajda@wp.pl 
Rozpad Związku Socjalistycznych Republik Radzieckich oraz powstanie niepodległej Republiki Tadżykistanu to na początku lat dziewięćdziesiątych $\mathrm{XX}$ wieku wydarzenia istotne dla posiadającego regionalne ambicje Teheranu. Nieco niespodziewanie na mapie świata pojawiło się nowe, kulturowo bliskie Iranowi państwo, umiejscowione pośród innych nowo powstałych, postradzieckich państw, związanych z kulturą centralno-azjatyckich Turków. Jedynie od południa Tadżykistan graniczy z perskojęzycznymi terenami Afganistanu, który również, opuszczony przez obecne ponad dekadę wojska Armii Czerwonej, stał się obiektem irańskich starań o wzmocnienie strefy wpływów ideologicznych, politycznych i gospodarczych. Wraz z zaistnieniem nowej rzeczywistości geopolitycznej i regionalnej niejako na nowo nabrała znaczenia ideologia „Wielkiego Iranu” ${ }^{1}$, która stopniowo zaczęła wywierać wpływ na perskojęzyczne i zamieszkane przez Tadżyków regiony Afganistanu i Tadżykistanu.

W niniejszym artykule, w oparciu o istniejące już prace badawcze oraz źródła prasowe w języku angielskim oraz językach regionu (perskim i tadżyckim), a także uwzględniając własne wnioski płynące z pobytów badawczych w Iranie, Afganistanie i Tadżykistanie, przeanalizuję politykę kulturalną i językową Islamskiej Republiki Iranu (IRI) w wymiarze zagranicznym i regionalnym, zawężoną odpowiednio do dwóch państw najbliższych Iranowi (pod względem językowym i kulturowym), którymi są Afganistan oraz Tadżykistan. Prezentowana tu analiza ma przede wszystkim charakter politologiczny, choć uzupełniona została o niezbędne informacje z dziedziny iranistyki, językoznawstwa czy kulturoznawstwa. Niniejszy artykuł ma charakter przekrojowy i stanowi jedynie formę wstępu do dalszych interdyscyplinarnych rozważań nad obszernym zagadnieniem, jakim są współczesne relacje trzech państw bliskich kulturowo i językowo. Za okres badawczy przyjmuję lata 1979-2014, od przełomowych wydarzeń rewolucji islamskiej w Iranie, a także wkroczenia do Afganistanu Armii Czerwonej, aż po zakończenie w Afganistanie prowadzonej przez siły Sojuszu Północnoatlantyckiego (NATO) misji ISAF ${ }^{2}$.

1 Wielki Iran (pers. Iran-e Bozorg, ang. Greater Iran) to pojęcie geograficzne określające wszystkie ziemie, które historycznie należały do perskich imperiów i zostały objęte irańskimi wpływami kulturowymi. Historyczny „Wielki Iran” obejmuje znaczące części regionu Bliskiego Wschodu, Kaukazu, Azji Centralnej i Azji Południowej. Obecnie pojęcia tego często używają paniraniści, których ideą jest odtworzenie wielkości imperium w nawiązaniu do Achemenidów, dla których matecznikiem byłby Iran. Patrz również: X. de Planhol, Iran: i. Lands of Iran [w:] Encyclopaedia Iranica, [www 10].

${ }^{2}$ ISAF - akronim, The International Security Assistance Force (Międzynarodowe Siły Wsparcia Bezpieczeństwa). 


\section{Terminologia}

Poruszając tematykę polityki kulturalnej oraz językowej, należy wyjaśnić te pojęcia oraz wskazać ich miejsce w niniejszej analizie. Polityka kulturalna obejmuje działania władz publicznych i organizacji pozarządowych zarówno w zakresie kultury i sztuki, jak również tożsamości kulturowej i społecznej. Zazwyczaj jest ona przedmiotem analizy w kontekście lokalnym bądź wewnątrzpaństwowym, a jej pozapaństwowe wyznaczniki opierają się o działania organizacji międzynarodowych, takich jak UNESCO. Polityka kulturalna jest jednak z pewnością obecna również w dyplomacji i relacjach bilateralnych państw, szczególnie zbliżonych kulturowo (na przykład Polski i Białorusi tudzież Polski i Ukrainy). W tym kontekście pojawia się również pojęcie dyplomacji kulturalnej, która funkcjonuje na zasadzie wymiany idei, informacji oraz sztuki, a także pozostałych aspektów kultury pomiędzy narodami w celu wzajemnego zrozumienia ${ }^{3}$. Mając na uwadze bogate spektrum działań dyplomatycznych Iranu względem Afganistanu i Tadżykistanu, postaram się wyodrębnić aspekty polityki kulturalnej spośród ogółu działań Teheranu prowadzonych w celu zbliżenia politycznego, ideologicznego i gospodarczego z rzeczonymi państwami. Polityka językowa z kolei najpełniej może być zdefiniowana jako ogół działań podejmowanych w pewnej społeczności celem kształtowania stosunku do języka oraz oblicza komunikacji w niej, a także w kontaktach z innymi społecznościami ${ }^{4}$. W wypadku trójstronnych relacji Afganistan - Iran - Tadżykistan jej oblicze najpełniej wyraża się w opisanej poniżej idei Unii Państw Perskojęzycznych (patrz: 5. Rozwój idei Unii Państw Perskojęzycznych).

W kontekście prowadzonej analizy wyjaśnienia wymaga także sam termin „Iran”, który ma w tym wypadku szerokie znaczenie i wywodzi się od tego samego źródłosłowu staroperskiego (etnonimu arja ${ }^{5}$ ), co współczesny perski toponim „Arjan”, czyli Ariowie ${ }^{7}$. Współczesny termin „Iran” jako „Eran” pojawia się na inskrypcji Ardaszira I (224-242) w Naqsz-e Rustam

3 M. C. Cummings, Cultural Diplomacy and the United States Government: A Survey, s. 1.

4 S. Gajda, Promocja jezzyka $i$ kultury polskiej a procesy uniwersalizacji $i$ nacjonalizacji kulturowo-językowej wświecie, s. 11.

5 Patrz: H. W. Bailey, Arya [w:] Encyclopaedia Iranica, [www 15].

${ }^{6}$ Patrz: R. Schmitt, Aryans [w:] Encyclopaedia Iranica, [www 16].

7 M. Składankowa, Zrozumieć Iran, s. 180. 
(i pochodzi od znanego już z Awesty ${ }^{8}$ określenia ojczyzny Ariów ${ }^{9}$, czyli Ariany. Termin ten można uznać w kontekście międzynarodowym za wyraz wspólnoty wszystkich ziem związanych historycznie ze starożytnymi imperiami Achemenidów czy Sasanidów. Warto zważyć, że określenie „Ariana” jest obecnie popularne nie tyle w samym Iranie, ile bardziej w Afganistanie i wykorzystywane bywa w wielu powstałych w XX i XXI wieku nazwach własnych, między innymi afgańskich linii lotniczych Ariana Afghan Airlines (rok zał. 1955) czy afgańskiej telewizji Ariana Afghanistan TV (rok zał. 2006). Świadomość irańskiego pochodzenia cywilizacji oraz „aryjskości”, a nawet „irańskości” narodu jest obecna również w Tadżykistanie, o czym świadczą między innymi tytuły wydawanych w Duszanbe publikacji naukowych, takich jak Tadżycy na terytorium Ariany ${ }^{10}$. Ta sama kwestia wraz ze wspólną historią afgańsko-irańską jest podkreślana przez irańskich redaktorów prac naukowych w tytułach opracowań, na przykład Iran i Afganistan - od jedności do ustanowienia granic politycznych ${ }^{11}$. Na podstawie tych informacji można postawić tezę, że historia ziem trzech wyżej wspomnianych państw przez długi czas płynęła jednym nurtem, w związku z czym w wielu opracowaniach, aż do wyodrębnienia się państwa afgańskiego w XVIII wieku oraz podboju Azji Centralnej przez Rosję w drugiej połowie XIX wieku, traktowana bywa po prostu jako „historia Iranu” ${ }^{12}$. Niejako na poparcie przytoczyć można słowa, które na temat korzeni swego państwa i narodu wypowiedział urzędujący prezydent Tadżykistanu Emomali Rahmon: „Tadżycy, których historia liczy tysiąclecia, według swojego pochodzenia należą do Aryjczyków i są rdzennymi mieszkańcami Azji Centralnej. Historia Tadżyków jest ściśle związana z historią wszystkich narodów grupy irańskiej" ${ }^{13}$, lub prezydenta

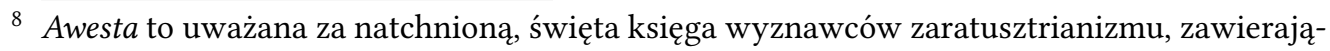
ca stare irańskie przekazy, datowane nawet na II tysiąclecie p.n.e.

9 R. Schmitt, op. cit.

${ }^{10}$ Todżikon dar Qalamrawi Orijono [Tadżycy na terytorium Ariany], M. Szukurzoda (red.).

${ }^{11}$ M. A. Bahman Qadżar, ايران و افغانستان از يخانكى تا تعيين مرزهاى سياسى Iran wa Afqanestan: Az jeganegi ta ta’jin-e marzha-je sijasi [Iran i Afganistan: Od jedności do ustalenia granic politycznych].

${ }^{12}$ A. Krasnowolska, Historia Iranu, s. 14.

${ }^{13}$ E. Rachmonow, Tadżycy w zwierciadle historii, s. 55. Szerzej o skomplikowanej tożsamości narodowej Tadżyków, odwołaniach do wspólnego historycznego dziedzictwa z Iranem i Afganistanem, próbach zniszczenia tych więzów przez władze ZSRR i wreszcie rekonstrukcji tożsamości w ramach niepodległego Tadżykistanu zob. np.: P. Niechciał, Tożsamość narodowa po tadżycku: Odtwarzanie koncepcji narodu i jego historii w przestrzeni publicznej Republiki Tadżykistanu, s. 169-182. 
GAJDA, Polityka językowa oraz kulturalna Islamskiej Republiki Iranu... 11

Iranu Mahmuda Ahmadineżada: „Iran i Tadżykistan są jednym duchem obecnym w dwóch ciałach" ${ }^{14}$.

\section{Wspólnota języka i kultury ponad wspólnotą re- ligii}

W kontekście analizy polityki Iranu wobec Afganistanu i Tadżykistanu istotną kwestią pozostaje dookreślenie sformułowań „świat irański” czy też „irańska sfera”, co John Perry wiąże z czynnikiem językowym, wyodrębniając strefę geograficzną, w której język perski stanowił lingua franca w okresie historycznym od XIII do XIX wieku n.e. ${ }^{15}$ Język perski oraz kultura z nim związana od setek lat wywierały wpływ na Azję Środkową ${ }^{16}$. Średnioperski miał ogromne znaczenie na terytorium Sasanidów (224-651 n.e.) zarówno jako język urzędowy imperium, jak i język kultu zaratusztriańskiego. Z kolei po najeździe arabskim nowoperski jako język handlu i dyplomacji był używany nie tylko przez Irańczyków, ale także stał się językiem urzędowym dworów kilku dynastii tureckiego pochodzenia, między innymi Ghaznawidów (997-1186) i Seldżuków (1040-1307), a także dworu Wielkich Mogołów (1526-1540, 1555-1857) w Indiach. Język perski jako nośnik kultury nie jednoczył zatem w przeszłości żadnej homogenicznej grupy etnicznej ludności irańskiej, ale był przyczyną „persjanizacji” społeczeństw pochodzących z innych kręgów kulturowych ${ }^{17}$.

Dziś perski pozostaje językiem urzędowym Iranu, zaś dari (afgańska odmiana perskiego) jest jednym z dwóch urzędowych języków Afganistanu i wraz z dialektami stanowi mowę ojczystą ponad 30\% mieszkańców tego kraju, głównie Tadżyków - drugiej co do wielkości (po Pasztunach) grupy etnicznej Afganistanu. Język dari, mimo że w afgańskiej konstytucji z 1964 roku występuje pod tą nazwą, przez samych użytkowników częściej jest nazywany po prostu językiem perskim (farsi). Również dialekty, takie jak

${ }^{14}$ Iran Forges Closer Ties with Tajikistan, eurasianet.org, [www 09].

${ }^{15}$ J. Perry, Folklore of the Iranian Region, s. 191-202.

${ }^{16}$ W. Johnston, Iran's Cultural Foreign Policy in Southern Asia and the Southern Caucasus since 1991, s. 109.

${ }^{17}$ Spersjanizowane społeczeństwo (ang. Persianate society lub Persified society) to społeczeństwo, na które silny wpływ mają język perski, literatura perska i perska kultura. Pojęcie wprowadzone przez M. Hodgsona [w:] The Venture of Islam. Conscience and History of a World Civilization (vol. II). 
hazaragi, którym posługują się afgańscy Hazarowie - ziranizowana ludność szyicka - są bliskie perszczyźnie. Dari jako język handlu i administracji znany jest również, przynajmniej w stopniu komunikatywnym, większości innych ludów Afganistanu, włącznie z dominującymi w tym kraju Pasztunami (choć i ci określają go najczęściej terminem parsi, czyli „perski”). Na niemal całym terytorium Afganistanu służy on do porozumiewania się na bazarach oraz w większości urzędów państwowych. Podobnie rzecz się ma z językiem tadżyckim, który - choć jest zapisywany cyrylicą i nie oparł się wpływom języka rosyjskiego oraz uzbeckiego - stanowi dialektalny wariant perskiego, bardzo bliski również językowi dari. Tadżycki został wyodrębniony z perszczyzny na początku XX wieku, kiedy ziemie te były już częścią Imperium Rosyjskiego, co miało również związek z budową tadżyckiej tożsamości narodowej i językowo-kulturowego odcinania Tadżyków od Iranu, Afganistanu i języka perskiego. Podobnie jak w Afganistanie, choć w nieco mniejszym zakresie, również w Tadżykistanie w powszechnym użyciu pozostaje określenie „język perski”. Mimo starań władz Rosji, a później Związku Radzieckiego oraz dominujących w Afganistanie Pasztunów, świadomość wspólnoty językowej nie została szczególnie naruszona. W praktyce użytkownicy języka perskiego (farsi), dari (dari) oraz tadżyckiego (todżiki) wciąż nie mają większych problemów w werbalnym porozumiewaniu się między sobą, co wreszcie w bardziej sprzyjającym momencie w historii wykorzystane zostało przez władze trzech wspomnianych państw jako baza do zacieśniania relacji między tak zwanymi państwami perskojęzycznymi ${ }^{18}$ : Afganistanem, Iranem i Tadżykistanem.

Jak wskazuje wielu irańskich badaczy stosunków międzynarodowych, między innymi Mohammad Ali Bahman Qadżar: „Iran i Afganistan dzielą ze sobą wspólną historię i kulturę"19. Co niezwykle wymowne, irański badacz nie decyduje się przy tym na tworzenie kontekstowego odniesienia do wspólnoty religijnej, wydawać by się mogło aspektu współcześnie kluczowego w świetle faktu, że wspomniane państwa dzielą z sobą tę samą formę systemu politycznego, którą jest republika islamska. Mimo iż zdecydowaną większość mieszkańców wszystkich trzech państw stanowią muzułmanie, to nie religię, lecz historię, kulturę i język należy uznać w tym dyskursie za czynniki kluczowe. Islam szyicki jako religia państwowa czyni Iran wyznaniowo odmiennym od kulturowo i językowo bliskich mu Afganistanu czy

\footnotetext{
${ }^{18}$ Per. keszwarha-je farsizaban, ang. Persian-speaking countries.

${ }^{19}$ M. A. Bahman Qadżar, op. cit., s. 18.
} 
Tadżykistanu (jakkolwiek również te państwa zamieszkują mniejszości szyickie). Warto dodać, że tereny te po islamizacji niemal od początku nie były homogeniczne, a zróżnicowanie w obrębie formy wyznawanego islamu istniało w pewnym sensie już na długo przed tym, jak Iran przyjął szyizm za religię państwową (1501). Na terenie dzisiejszego Iranu dominowała bowiem szkoła szafi'icka ${ }^{20}$, zaś na terenach dzisiejszego Afganistanu i Tadżykistanu więcej zwolenników mieli hanbalici' ${ }^{21}$.

Ponadto, można postawić tezę, że islam jako instrument polityki państwa, wpływający na kształtowanie współczesnej irańskiej kultury, komplikuje kwestie związane z tożsamością kulturową samego Iranu i jego mieszkańców. Jak zauważa Anna Krasnowolska: „[Porewolucyjna] rządowa polityka islamizacji kultury doprowadziła do jej rozwarstwienia. Nowa «muzułmańska» kultura przedstawiała sobą niespójną mieszankę elementów różnej proweniencji”"22.

\section{Kulturowe oblicze Islamskiej Republiki Iranu}

Współczesny Iran jest krajem wielokulturowym, zamieszkanym przez rozmaite grupy etniczne, językowe i religijne. Warto nadmienić, że już polityka Achemenidów wobec podbitych ludów charakteryzowała się w dużej mierze liberalizmem, tolerancją etniczną, kulturową i wyznaniową, co sprzyjało zarówno asymilacji, jak również przenikaniu się kultur wzbogacających rdzenną kulturę irańską. Od starożytności na rdzeń irańskiej kultury oddziaływały wielkie systemy filozoficzno-religijne, wśród których jako najbardziej wpływowe wyróżnić należy rdzennie irański zoroastryzm oraz islam przyniesiony na tereny Wyżyny Irańskiej przez arabskich najeźdźców. Zislamizowana kultura irańska, zrujnowana następnie w średniowieczu przez najazdy mongolskie, niezmiennie poddawana była wpływom kolejnych cywilizacji. W XIX i XX wieku były to głównie idee i kultura europejska. Oddziaływanie Okcydentu na Iran doprowadziło w minionym stuleciu do kilku kryzysów

${ }^{20}$ Wywodzi się od Asz-Szafi'iego (zm. 820), uznawanego za reformatora i systematyka prawa muzułmańskiego. Asz-Szafi'i uważa sunnę Proroka Mohammada za równoprawne obok Koranu źródło prawa. Jest twórcą takich metod, jak idżma (zgoda uczonych) i kijas (analogia).

${ }^{21}$ Szkoła hanbalicka wywodzi się od Ahmada Ibn Hanbala (zm. 855) i jest uznawana za najbardziej rygorystyczną ze szkół prawa muzułmańskiego. Hanbalici są konserwatywni i bezkompromisowi w obliczu interpretacji Koranu oraz Sunny. Kijas oraz idżma zostały odrzucone, a ibn Hanbal dążył do przywrócenia pierwotnej czystości religii i prawa.

${ }^{22}$ A. Krasnowolska, op. cit., s. 910. 
tożsamościowych w społeczeństwie, które między innymi zaowocowały powstaniem pejoratywnych terminów w języku perskim, takich jak qarbzade$g i^{23}$, oraz utrwaleniem poczucia poniżenia i urażonej dumy dziedziców wielkiej starożytnej cywilizacji. Ostatni szach Iranu - Mohammad Reza Pahlawi (1941-1979), który starał się łączyć zachodnie idee z przedislamską spuścizną wielkich irańskich dynastii Achemenidów czy Sasanidów, jednocześnie deprecjonował rolę społeczną islamu i szyickiego kleru, który uznawał za element zagrożenia dla swojej pozycji i autorytetu. Dlatego też kręgi związane $\mathrm{z}$ islamem stopniowo transformowały się $\mathrm{w}$ znaczącą siłę opozycyjną, a kultura muzułmańska stała się w Iranie alternatywą dla mieszanki kultury rdzennie irańskiej i zachodniej. Wiele zmieniło się w oficjalnej linii ideologicznej rządu, gdy po rewolucji w 1979 roku Iran oficjalnie ogłoszony został republiką islamską. W następstwie tego w porewolucyjnej rzeczywistości islam stał się naczelnym czynnikiem kształtującym wszystkie wymiary życia, w tym współczesną irańską kulturę i politykę zagraniczną.

Polityka kulturalna w wymiarze wewnętrznym oraz jej instrumenty stosowane przez Iran w relacjach z państwami omawianych regionów są bardzo istotnymi czynnikami stanowiącymi o sile i integralności kraju, a także o możliwościach umacniania wpływów w otoczeniu międzynarodowym. Nie skupiając się w tym artykule na polityce kulturalnej w aspekcie wewnątrzpaństwowym, a opisując jedynie jej wymiar zewnętrzny jako instrumentu politycznego oddziaływania regionalnego, tzw. softpower, należy wskazać, że hasła eksportu rewolucji islamskiej z początku lat osiemdziesiątych XX wie$\mathrm{ku}$, tak w sensie politycznym, jak i kulturowym, stały się w regionie nie tyle zachętą do pójścia drogą ajatollaha Ruhollaha Chomejniego, ile raczej źródłem niepokoju dla elit państw rządzonych przez sunnitów, a zamieszkanych również przez społeczności szyickie. Idee rewolucji islamskiej jako obce, niekiedy „sekciarskie”, spotykały się z niechęcią i odrzuceniem, a także z otwartą wręcz wrogością sunnickich elit władz państw ościennych. Tak było na przykład w Iraku, zdominowanym przez szyitów, a rządzonym przez wywodzącego się ze społeczności sunnickiej Saddama Husajna, z którym Iran prowadził wojnę w latach 1980-1988. Niepokój związany z ideologią nowych władz Iranu wkrótce zapanował też w Związku Radzieckim. Nie tyle sama rewolucja islamska (wszak przez nią Iran wyszedł z amerykańskiej strefy wpływów), ile jej następstwa, gdy reżim Chomejniego zaczął eliminować

\footnotetext{
${ }^{23}$ Pers. qarbzadegi to spopularyzowany w latach sześćdziesiątych XX wieku termin o znaczeniu pejoratywnym, który najczęściej tłumaczy się jako „zarażenie Zachodem”.
} 
GAJDA, Polityka językowa oraz kulturalna Islamskiej Republiki Iranu... 15

z irańskiej sceny politycznej między innymi przedstawicieli komunistycznej partii Tude (wcześniej irańscy rewolucjoniści byli zapraszani do ZSRR i Kabulu, gdzie już wtedy rządzili wspierani przez Sowietów komuniści), a także obawa przed ekspansją rewolucji na tereny Afganistanu, Azji Centralnej czy Kaukazu, uznawane są za jedne z czynników, które wpłynęły na podjęcie przez ZSRR decyzji o interwencji w Afganistanie w grudniu 1979 roku.

\section{4 Źródła współczesnej polityki kulturalnej IRI w wymiarze zagranicznym}

Za istotny akt nowożytnej polityki kulturalnej prowadzonej przez władze w Teheranie w przestrzeni międzynarodowej należy uznać wydarzenie z 1935 roku, kiedy to na wniosek szacha Rezy Pahlawiego Ministerstwo Spraw Zagranicznych pisemnie zwróciło się do przedstawicielstw dyplomatycznych w Teheranie o używanie w oficjalnej korespondencji określenia „Iran” zamiast dotychczas stosowanego terminu „Persja” ${ }^{24}$. Od tamtej chwili w dokumentach dyplomatycznych korzystano z tej nazwy (jakkolwiek w późniejszym czasie syn Rezy Pahlawiego - szach Mohammad Reza nie sprzeciwiał się korzystaniu z obu terminów zamiennie). Wspomniany nacisk wiązał się z politycznymi sympatiami założyciela dynastii Pahlawich. Irański władca, podobnie jak wielu wysoko urodzonych Irańczyków w owym czasie ${ }^{25}$, reprezentował poglądy proniemieckie. Niektóre źródła wskazują nawet, jakoby sugestia oficjalnej zmiany używanego terminu miała wypłynąć od będącego pod wpływem nazistowskiej ideologii niemieckiego ambasadora w Teheranie $^{26}$. W czasach międzywojennych naziści poszukiwali w Azji, wśród ludów uchodzących za aryjskie, dowodów na ich pokrewieństwo z narodem niemieckim, dążąc przy tym do zbliżenia ze wszystkimi narodami „szlachetnego - aryjskiego” pochodzenia. Co istotne, w tym samym czasie Iran starał się zrzucić piętno zakończonej zaledwie kilka lat wcześniej brytyjsko-rosyjskiej „Wielkiej Gry”, której kluczowymi elementami były działania na rzecz pozyskania wpływów w Azji. Zważyć należy, że zarówno w Moskwie, jak i w Londynie decydowano o ich prowadzeniu między innymi poprzez starania na

\footnotetext{
${ }^{24}$ Warto zauważyć, że w wielu pracach, jak również potocznie uważa się, że szach zmienił nazwę rządzonego przez siebie państwa. Nie jest to jednak twierdzenie zgodne z prawdą.

${ }^{25}$ M. Składankowa, op. cit., s. 180-181.

${ }^{26}$ Patrz: E. Yarshater, Persia or Iran.
} 
rzecz osłabienia Persji i wyodrębnienia z państwa perskiego narodów niebędących Persami tak na Zakaukaziu, jak i w historycznym Chorasanie, co naturalnie miało osłabić siłę oddziaływania politycznego i kulturowego Iranu w regionie. Ideologia wieloetnicznego i wielokulturowego Iranu szacha Rezy Pahlawiego była zatem próbą uratowania przed rozpadem okrojonych terytorialnie w toku „Wielkiej Gry” ziem Iranu i miała z założenia sprawdzić się jako cementująca zarówno w stosunku do Persów, jak i innych ludów irańskiego pochodzenia, takich jak Beludżowie, Kurdowie, Lurowie czy Bachtiarzy. Umocowanie w przestrzeni międzynarodowej terminu „Iran” miało również w przyszłości wywrzeć wpływ na rozwój relacji z innymi państwami regionu, głównie Afganistanem i mającym powstać kilkadziesiąt lat później (w 1991 roku) Tadżykistanem. W rzeczywistości lat trzydziestych XX wieku w Afganistanie rozkwitała afgańska (pasztuńska) ideologia narodowa, której przedstawiciele przejawiali duże obawy przed wszelkimi ideami związanymi w jakikolwiek sposób z paniranizmem i starali się w miarę możliwości deprecjonować rolę języka perskiego na rzecz paszto ${ }^{27}$.

\subsection{Kultura i język - irańskie instrumenty typu soft power w polityce zagranicznej}

Po wyjściu Armii Czerwonej z Afganistanu w 1989 roku i rozpadzie Związku Radzieckiego Iran zdecydowanie przeformułował strategię oddziaływania na swego wschodniego sąsiada również ze względu na konieczność doboru skutecznych instrumentów politycznych wobec nowo powstałych postradzieckich republik w regionie Azji Centralnej. Drugim wydarzeniem, które można uznać za katalizator zmiany narzędzi irańskiej polityki zagranicznej i propagandy, była śmierć ajatollaha Ruhollaha Chomejniego w czerwcu 1989 roku. Po odejściu duchowego ojca nowego ustroju w Iranie odnotowano stopniowy powrót trendów panirańskich i nacjonalistycznych, które zarówno w świadomości polityków, jak i społeczeństwa zaczęły przenikać się i niejako konkurować z panislamskimi ideami rewolucji. W stosunkach międzynarodowych objawiło się to w sposób szczególny w polityce kulturalnej. Jakkolwiek już kilka miesięcy po rewolucji islamskiej nowe władze Republiki Islamskiej próbowały dotrzeć ze swoją propagandą do Afganistanu i sowieckiej Azji Centralnej ${ }^{28}$, irański fundamentalizm szyicki związany z koncepcją

\footnotetext{
${ }^{27}$ A. Saikal, Modern Afghanistan: A History of Struggle and Survival, s. 112-113.

${ }^{28}$ Patrz: D. Hiro, Iran: The Geopolitics of the Islamic Revolution, s. 375.
} 
mardża'-e taqlid ${ }^{29}$ (czy też welajat-e faqih) okazał się nieefektywnym narzędziem politycznym w zdominowanym przez suficko-sunnickie ryty Afganistanie i Tadżykistanie ${ }^{30}$. Tadżycki postkomunistyczny rząd prezydenta Rahmona Nabijewa był zwolennikiem sekularyzmu, a liderzy Partii Islamskiego Odrodzenia Tadżykistanu (tadż. Hizbi Nahzati Islomii Todżikiston) nie stawiali Iranu w roli modelu do naśladowania. Iran jako pierwsze państwo, które otworzyło swoją ambasadę w niepodległym Tadżykistanie, od początku prowadził jednak działania w zakresie kulturalnym poprzez organizowanie w Duszanbe konferencji i festiwali filmowych. W Tadżykistanie pojawiły się również irańskie książki i czasopisma. Bardziej istotne było jednak w owym czasie wsparcie ze strony Teheranu dla niektórych frakcji opozycji tadżyckiej; w czasach wojny domowej na emigrację do Iranu udał się między innymi Szodmon Jusuf, założyciel Demokratycznej Partii Tadżykistanu (tadż. Hizbi Demokratii Todżikiston), a także wielu działaczy innych ugrupowań. Teza, że władze w Teheranie całkowicie zrezygnowały z zamiaru budowy strefy wpływów na wschodzie w oparciu o korzystanie z instrumentów oraz ideologii religijnych, nie jest jednak do końca prawdziwa, o czym świadczy irańskie wsparcie dla szyickich społeczności afgańskich Hazarów, udzielane w czasie dominacji w Afganistanie sunnickiego, wspieranego przez Pakistan, Ruchu Talibów ${ }^{31}$. W latach dziewięćdziesiątych XX wieku kwestie związane z kulturowym, etnicznym i językowym pokrewieństwem stały się dominującym, choć nie jedynym instrumentem irańskich starań na rzecz zbliżenia z Tadżykistanem i Afganistanem. Co bardzo istotne, jest to precedens w historii polityki zagranicznej prowadzonej przez istniejącą od dekady Islamską Republikę Iranu.

\section{Rozwój idei Unii Państw Perskojęzycznych}

Za pierwszy formalny akt nowej polityki kulturowej Iranu uznać należy podpisanie porozumienia o współpracy kulturalnej pomiędzy posługującymi się wariantami języka perskiego Tadżykami, Afgańczykami oraz Irańczykami z nowo powstałym rządem Republiki Tadżykistanu i najstarszą afgańską

\footnotetext{
${ }^{29}$ Mardiza'-e taqlid (arab. mardża al-taghlid) - najwyższy autorytet w szyizmie, którego orzeczeniom w kwestiach religijno-obyczajowych powinni poddawać się wierni.

${ }^{30}$ Patrz: A. Muhatir, Afghanistan and Tadjikistan: Destablishing Factors for South and Central Asian Region.

${ }^{31}$ Patrz: ibidem.
} 
partią integrującą środowisko Tadżyków z północno-wschodniego Afganistanu - Dżamijat-e Eslami Burhanoddina Rabbaniego ${ }^{32}$. Wraz z tym porozumieniem powstała koncepcja utworzenia Unii Państw Perskojęzycznych opartej na pokrewieństwie kulturowo-językowym, która była dyskutowana przez rządy Iranu, Afganistanu i Tadżykistanu podczas spotkań na szczycie w latach 2002-201233. Czynnikiem sprzyjającym były działania z zakresu polityki kulturalno-tożsamościowej, które od 1997 roku podjął w Tadżykistanie prezydent Rahmon w celu zminimalizowania wpływu islamu na politykę i społeczeństwo. Były one definiowane w oparciu o trzy pojęcia: aryjską cywilizację, samanidzkie dziedzictwo i zoroastryzm ${ }^{34}$.

Kultura i język okazały się produktywnymi narzędziami politycznymi w rękach irańskich władz, o czym świadczą konkretne wydarzenia historyczne. W latach dziewięćdziesiątych XX wieku, w wyniku irańskiej polityki wspierania grup perskojęzycznych w Afganistanie, Islamskiej Republice Iranu udało się znacznie poszerzyć wpływy wśród członków Sojuszu Północnego ${ }^{35}$, który po odsunięciu od władzy Ruchu Talibów w 2001 roku stał się najpotężniejszą siłą polityczną w kraju Dobre relacje z rządem prezydenta Hamida Karzaja związane były także z możliwościami wywarcia wpływu na przedstawicieli Sojuszu Północnego, jakimi Iran dysponował na zorganizowanej pod auspicjami ONZ konferencji w Bonn w 2001 roku. Jak twierdzi przedstawiciel amerykańskiej administracji rządowej James Dobbins, to „działania Iranu umożliwiły wypracowanie porozumienia, które pozwoliło Hamidowi Karzajowi stanąć na czele afgańskiego państwa" ${ }^{6}$. Jednym z fundamentów takiego stanu rzeczy była niewątpliwie dotychczasowa skuteczna polityka kulturalna i wspieranie bliskich kulturowo i językowo grup afgańskich. Wpływy rządu irańskiego wśród afgańskich Tadżyków - zwolenników Rabbaniego i zabitego we wrześniu 2001 roku Ahmada Szaha Mas'uda - umożliwiły osiągnięcie porozumienia i uzyskanie wsparcia ze strony Sojuszu Północnego dla zaakceptowanej przez Teheran kandydatury Karzaja - Pasztuna mieszkają-

${ }^{32}$ A. Awady, Saudi Arabia, Iran and the Conflict in Afghanistan, s. 122.

${ }^{33}$ Patrz: J. Gajda: Afganistan - Iran - Tadżykistan. Relacje państw perskojęzycznych w 2010 roku, s. $79-86$.

${ }^{34}$ E. Marat, Imagined Past, Uncertained Future - the Creation of National Ideologies in Kyrgyzstan and Tajikistan, s. 18-23.

35 Zawiązany w 1992 roku sojusz militarno-polityczny, odtworzony w 1996 roku, po przejęciu władzy w Kabulu przez Ruch Talibów. Na czele stanął wówczas Burhanoddin Rabbani, a dowódcą wojskowym został Ahmad Szah Mas'ud.

${ }^{36}$ J. Dobbins, Negotiating with Iran: Reflections from Personal Experience, s. 153-154. 
cego wcześniej w Stanach Zjednoczonych - na urząd szefa afgańskiego rządu tymczasowego. Przez okres dwóch kadencji prezydenckich Karzaj doceniał irańskie wsparcie, co w tym okresie wydatnie przyczyniło się do dalszego rozwoju relacji afgańsko-irańskich, a także postępów w pracach nad projektem Unii Państw Perskojęzycznych. Nastawienie na zacieśnienie relacji Iranu z Afganistanem i Tadżykistanem, odwołujących się do wspólnoty języka perskiego oraz dziedzictwa kulturowego, wiąże się z rządami Mahmuda Ahmadineżada. W okresie jego prezydentury (2005-2013) odbyły się cztery szczyty państw perskojęzycznych, podczas których dyskutowano na temat formalnych warunków politycznej, gospodarczej oraz kulturowej integracji. W 2008 roku doszło również do zainicjowania projektu Rady Ekonomicznej Unii Państw Perskojęzycznych, która była kolejnym etapem na drodze do integracji - już nie tylko w wymiarze językowo-kulturowym, ale i gospodarczym $^{37}$.

\subsection{Polityczny wymiar święta Nouruz}

$\mathrm{Z}$ uwagi na fakt, iż fundamentami zbliżenia politycznego i gospodarczego były język perski i wspólne dziedzictwo kulturowe, okazjami do trójstronnych spotkań polityków i dyplomatów na różnych szczeblach stały się w szczególności wydarzenia kulturalne. W tym kontekście należy podkreślić szczególną, integrującą rolę ceremonii irańskiego nowego roku - Nouruzu ${ }^{38}$, który celebrowany jest we wszystkich trzech państwach, a także w krajach sąsiadujących z nimi, niezwiązanych bezpośrednio z irańskim kręgiem kulturowym. Od 2009 roku przez pięć kolejnych lat zwyczajem stało się, że noworoczne oficjalne obchody odbywały się wspólnie, w obecności najwyższych przedstawicieli władz Afganistanu, Iranu i Tadżykistanu. Ahmadineżad, Karzaj i Rahmon spotykali się kolejno w afgańskim Mazar-e Szarif (2009), irańskim Szirazie (2010) i Teheranie (2011), następnie w stolicy Tadżykistanu - Duszanbe (2012) oraz turkmeńskim Aszhabadzie (2013). Wybór na miejsce obchodów stolicy Turkmenistanu mógł wszakże zwiastować rozmycie się idei zbliżenia wyłącznie na gruncie państw perskojęzycznych, blisko związanych z kulturą irańską. W 2014 roku, na ostatnich jak dotąd wspólnych obcho-

37 S. Medrea, Persian-Speaking Union created by Afghanistan, Iran, Tajikistan, [www 01].

${ }^{38}$ Nouruz (zapisywane też jako Nevruz, Newroz, Navruz, Nowruz, Naurız, Nooruz, Novruz, Navrez) - irańskie święto nowego roku, obchodzone w dniu równonocy wiosennej. W 2010 roku zostało uznane za święto międzynarodowe przez ONZ: General Assembly Recognizes 21 March as International Day of Nowruz, [www 11]. 
dach święta w Kabulu, Mahmuda Ahmadineżada zastąpił nowo wybrany prezydent Iranu - Hasan Rouhani. Z formuły wspólnych międzynarodowych obchodów zrezygnowano bez podania przyczyny w 2015 roku, a prezydent Rouhani zdecydował się jedynie na przesłanie świątecznego listu do prezydentów Afganistanu i Tadżykistanu, a także głów siedmiu innych państw, w których obchodzony jest Nouruz ${ }^{39}$. Podobnie rzecz się miała w 2016 roku, kiedy to nie doszło do świątecznego spotkania na szczycie, zaś Hasan Rouhani zdecydował się na rozmowę telefoniczną z prezydentem Afganistanu Aszrafem Ghanim i ponowne przesłanie listów z życzeniami do głów innych państw obchodzących Nouruz ${ }^{40}$.

Obchody święta Nouruz można uznać za znakomity wyznacznik woli i poziomu zaangażowania Iranu, Afganistanu i Tadżykistanu w proces kulturowej i językowej integracji w minionych latach. Zaprzestanie wspólnych obchodów w 2015 roku należy odczytać jako rzeczywistą i wymowną oznakę wstrzymania procesu integracyjnego, który faktycznie osłabł już wcześniej - w połowie drugiej kadencji prezydentury Ahmadineżada. Choć do 2014 roku odbywały się coroczne spotkania głów państw w ramach obchodów Międzynarodowego Święta Nouruz, to jednak ich forma utraciła trójstronny charakter, gdyż uczestniczyli w nich także przedstawiciele władz innych państw (między innymi Pakistanu i Turkmenistanu). W latach 2011-2014, poza wspólnymi obchodami Nouruzu, nie odbył się ani jeden formalny szczyt przywódców państw perskojęzycznych. Ostatni (czwarty) trójstronny szczyt, który miał przygotować grunt pod powstanie Unii Państw Perskojęzycznych, zorganizowano w Teheranie w 2010 roku. Projekt zaczął się zatem rozmywać. W latach 2012-2014 w mediach pojawiały się nieliczne doniesienia o rozwoju idei Unii Państw Perskojęzycznych, a politycy każdej z zaangażowanych stron rzadko wypowiadali się na ten temat.

\subsection{Przyczyny spowolnienia procesu integracji}

Zacieśnianie współpracy afgańsko-irańsko-tadżyckiej, budowane na kanwie językowych i kulturowych podobieństw, zeszło na dalszy plan głównie ze względu na zmianę uwarunkowań międzynarodowych. Duży wpływ na zahamowanie procesu miała polityka zagraniczna siły napędowej projektu Iranu, który na początku drugiej dekady XXI wieku został zmuszony, by

${ }^{39}$ Rouhani congratulates regional Leaders on Nouruz, Mehr News Agency, [www o2].

${ }^{40}$ Iran, Afghanistan Underline Expansion of All-Out Ties, Fars News, [www 03]. 
ponownie skoncentrować się na niepokojących wydarzeniach w Iraku oraz Syrii, będących również terenami jego strategicznego zaangażowania. Niebagatelne znaczenie odegrało bezpośrednie zagrożenie sunnickim fundamentalizmem i takfiryzmem ze strony tak zwanego Państwa Islamskiego, co wzbudziło zaniepokojenie w Teheranie. W kontekście nowych konfliktów w regionie kwestie współpracy kulturalnej ze wschodem i tworzenie Unii Państw Perskojęzycznych przestały być uznawane za priorytetowe.

Kolejnym czynnikiem hamującym owe inicjatywy była obawa przed indoktrynacją ideologiczną o podłożu religijnym w Tadżykistanie i Afganistanie. Rosnąca rola Iranu w tych państwach, zarówno w wymiarze kulturowym, jak i politycznym czy gospodarczym, została zauważona na początku drugiej dekady XXI wieku przez Moskwę oraz Waszyngton. Z naciskami Rosji (w Azji Centralnej) i Stanów Zjednoczonych (w Afganistanie) można wiązać tendencje - odczuwalne zarówno w Duszanbe, jak i Kabulu do dystansowania się od wpływów Iranu, włączając w to wpływy o podłożu kulturowym. Taki stan rzeczy wyniknął również z faktu, że polityka językowo-kulturalna Teheranu wobec Azji Centralnej i Afganistanu, choć w założeniach oparta na wspólnym, jeszcze przedislamskim dziedzictwie, zaczęła być wiązana z oddziaływaniem ideologicznym o podłożu religijnym. W takim postrzeganiu tego zjawiska dopomogło również samo stanowisko władz irańskich, które w 2011 roku, w obliczu tak zwanej Arabskiej Wiosny, oświadczyły między innymi, że fale rewolucji w państwach arabskich to forma „odpowiedzi na wezwanie do rewolucji islamskiej” z 1979 roku $^{41}$. Wymiar ideologiczno-religijny zaczął wedle opinii publicznej zdecydowanie przesłaniać aspekt kulturalny i językowy pilotowanego przez Iran zbliżenia. Analityk Parwiz Mullodżanow zauważa, że liczni tadżyccy studenci, którzy przebywali w czasie studiów na stypendiach w Iranie, przyjęli szyizm, a po powrocie do ojczyzny zaczęli organizować szyickie grupy studyjne na terenie tadżyckich uniwersytetów ${ }^{42}$. Podobne sytuacje dotyczą również Afganistanu, gdzie według doniesień płynących ze źródeł lokalnych wiele uczelni wyższych stroni od przyjmowania do pracy wykładowców, którzy zdobywali swe stopnie naukowe na uczelniach w Iranie, w obawie przed szerzeniem przez nich idei rewolucji islamskiej. Jesienią 2011 roku prezydent Rahmon wezwał prawie półtora tysiąca tadżyckich studentów, którzy studiowali

${ }_{41}$ Islamic Awakening Modeled on Iran Revolution, Press TV, [www 04].

${ }^{2}$ Tajikistan and Iran: is Dushanbe Distancing Itself from Cultural Cousin?, eurasianet.org, [www 05]. 
w krajach Bliskiego Wschodu, w tym również dwustu przebywających w Iranie, do rezygnacji z dalszej edukacji poza ojczyzną i niezwłocznego powrotu do $\mathrm{kraju}^{43}$. Równolegle pojawiły się doniesienia o problemach związanych z wyjazdem na kursy nauczycielskie do Teheranu, na których tadżycka kadra miała się uczyć alfabetu persko-arabskiego. W grudniu tego samego roku około dziewięćdziesięcioro dzieci przestało uczęszczać do szkoły prowadzonej przy irańskiej ambasadzie w Duszanbe ${ }^{44}$. Należy dodać, że ochłodzenie następowało nie tylko na płaszczyźnie kultury i edukacji. W omawianym okresie również kilku tadżyckich i irańskich ministrów odwoływało wzajemne wizyty, między innymi w lutym 2012 roku irański minister przemysłu i górnictwa Ali Akbar Mehrabian nie stawił się na irańsko-tadżyckim spotkaniu dotyczącym współpracy. W tym samym miesiącu irański wiceprezydent Hamid Baqa'i odwołał spotkanie z prezydentem Rahmonem, podczas którego miało nastąpić przekazanie zaproszenia na obchody święta Nouruz prezydentowi Ahmadineżadowi. Irańskie władze wyraziły również w tym czasie swe niezadowolenie ze zmniejszenia liczby połączeń lotniczych między Duszanbe i Teheranem przez tadżyckie linie lotnicze. Mimo to kwestie powstania Unii Państw Perskojęzycznych były dyskutowane na spotkaniach przedstawicieli niższej rangi. Oficjalnie władze trzech państw nadal uznawały ją za istotną i nie deprecjonowały znaczenia projektu. We wrześniu 2013 roku, na spotkaniu z nowo zaprzysiężonym ambasadorem Tadżykistanu w Teheranie - Nematullohem Imomzodą, prezydent Rouhani zwrócił uwagę na ogromną wagę relacji między Iranem, Afganistanem oraz Tadżykistanem, podkreślając, że rozwój każdego z tych trzech państw będzie działał na korzyść całego regionu. Wezwał też do dalszego pogłębiania relacji bilateralnych Duszanbe z Teheranem ${ }^{45}$. Z kolei w grudniu 2013 roku irański wiceminister kultury Hosejn Nuszabadi podczas rozmowy z ministrem kultury i informacji Afganistanu oświadczył, że powstanie Unii Państw Perskojęzycznych jest konieczne dla dobra języka perskiego, którym posługuje się na świecie około $100 \mathrm{mln}$ osób. Powstanie Unii było jego zdaniem niezbędne, by chronić status języka perskiego. Zaproponował przy tym powołanie wspólnego komitetu na rzecz integracji z oficjalnymi przedstawicielstwami w Iranie oraz Afganistanie ${ }^{46}$.

43 Ibidem.

${ }^{44}$ Ibidem.

45 President Rouhani urges expansion of ties among Persian-speaking countries, IRNA, [www o6].

${ }^{46}$ U. Niayesh, Deputy Minister: Iran welcomes Persian-speaking countries' union, Trend.az, [www 07]. 
GAJDA, Polityka językowa oraz kulturalna Islamskiej Republiki Iranu... 23

\subsection{Projekt wspólnego kanału telewizyjnego}

Najlepszym przykładem braku porozumienia w zakresie współpracy i integracji kulturowo-językowej okazała się historia trójstronnego projektu pierwszej ponadnarodowej telewizji Nawrooz TV. Decyzja o utworzeniu perskojęzycznego kanału telewizyjnego, skierowanego do widzów mieszkających w trzech państwach zainteresowanych rozwojem współpracy, została podjęta w 2006 roku na szczycie państw perskojęzycznych, w którym wzięli udział prezydenci Ahmadineżad, Karzaj i Rahmon. Na mocy kolejnego porozumienia, podpisanego w 2008 roku, ustalono, że studio telewizyjne zlokalizowane będzie w Duszanbe, koszty wyposażenia i sprzęt nadawczy zapewni strona irańska, zaś o sprzęt do nagrywania audycji postara się strona afgańska. Według informacji dostępnych w środkach masowego przekazu po decyzji o udostępnieniu lokalu przez tadżyckie władze Iran zainwestował w sprzęt równowartość ponad $1 \mathrm{mln}$ euro i wysłał go do Tadżykistanu ${ }^{47}$. Im bliżej było jednak do realizacji projektu, tym więcej pojawiało się wokół niego kontrowersji. Przede wszystkim malało zainteresowanie wdrożeniem projektu ze strony władz Tadżykistanu. Od 2011 roku i tak zwanej Arabskiej Wiosny, skutkującej przemianami politycznymi w świecie muzułmańskim, prezydent tego kraju zdecydowanie odsunął się od projektów kulturalnych, w których choćby w najmniejszym stopniu odgrywał rolę czynnik muzułmański. Jego poglądy zradykalizowały się w tej kwestii po odsunięciu od władzy wielu polityków sprawujących autorytarną władzę w swoich państwach, a także w związku z wojną z tak zwanym Państwem Islamskim w Syrii i Iraku, na którą zaczęli wyjeżdżać także obywatele Tadżykistanu ${ }^{48}$. Mimo że w stosunku do tak zwanego Państwa Islamskiego Duszanbe, Kabul i Teheran zajmowały podobne stanowiska, to jednak w stolicy Tadżykistanu zdecydowanie odżyły obawy, że projekt wspólnej telewizji może stać się „propagandową tubą" Iranu ${ }^{49}$, który wciąż formalnie nie zrezygnował z haseł nawołujących do eksportu rewolucji islamskiej. Takie stanowisko oczywiście nie zostało wypowiedziane wprost. Stąd też prawdopodobnie mogły się pojawić problemy na pozór niezwiązane z samą wymową ideologiczną projektu Nawrooz TV. Posunięcia władz Tadżykistanu dobitnie świadczyły jednak o chęci

\footnotetext{
${ }^{47}$ M. Momin, S. R. Sarvinozi, Af-Taj 2013: Sound, lights, inaction!, Afghanistan-Today.org, [www 08].

$4^{8}$ KDAM: Dar Surija taqiban 300 nafar szarwandoni Todżikeston medżangand [W Syrii walczy trzystu obywateli Tadżkistanu], ASIA-Plus, [www 13].

49 Tajikistan and Iran..., op. cit.
} 
blokowania wspólnie podjętej inicjatywy. W 2013 roku kraj ten zażądał zapłaty ceł za sprzęt przeznaczony na wyposażenie studia, który zgodnie z umową miał być zapewniony przez stronę irańską. Władze Iranu nie zgodziły się na zapłatę kwoty około 400 tys. euro, twierdząc, że jest to sprzęt na poczet wspólnego projektu i winien być zwolniony z obciążeń celnych ${ }^{50}$.

Kolejnym obszarem sporu, tym razem w wymiarze kulturowym i socjologicznym, była zawartość programowa nowego, międzynarodowego kanału oraz kwestie obyczajowe związane między innymi z ubiorem prowadzących. Tutaj ujawniły się wszystkie kulturowe różnice pomiędzy nakazami obyczajowymi w Iranie i Afganistanie a ich brakiem w świeckim Tadżykistanie ${ }^{51}$. Najczęściej podnoszoną kwestią było pytanie o zasadność zasłaniania włosów przez prezenterki. Jako kolejny czynnik wskazać należy wspomniane już obawy strategicznych partnerów Afganistanu i Tadżykistanu przed rozszerzeniem strefy wpływów Iranu. Zarówno Rosja, obawiająca się o swe centralnoazjatyckie „miękkie podbrzusze”, jak i obecne militarnie w Afganistanie Stany Zjednoczone mogły czuć niezadowolenie z powodu działań w sferze kulturowej mających na celu wzmocnienie projektu perskojęzycznego pod przewodnictwem najmocniejszego spośród trzech państw - Iranu. Projekt okazał się również kontrowersyjny w Afganistanie z uwagi istnienie w tym państwie drugiego języka urzędowego - paszto. Posługująca się nim ludność pasztuńska, w dużej części znająca też język dari, postulowała konieczność włączenia audycji w języku paszto w ramówkę stacji, w której tworzeniu oficjalnie partycypuje ich ojczyzna. Ponadto, do kontrowersyjnych zaliczyć można kwestię wymowy dialektalnej języka perskiego, w którym miały być nadawane audycje. Również w tym wypadku każde z państw stało na stanowisku, że przyjęta przez nie forma języka urzędowego jest formą właściwą ${ }^{52}$.

Choć według zapewnień irańskiego ambasadora w Duszanbe telewizja miała zacząć nadawanie najpóźniej w 2011 roku $^{53}$, do końca 2016 roku nie zainaugurowano jej działania.

\footnotetext{
${ }^{50}$ Ibidem.

${ }^{11}$ E. Adinabay, Changing Media and Politics in Tajikistan, [www 14].

${ }^{52}$ R. Dawlat, Szikwai Eron az muszkiloti taszkili TV-i forsizabonon, Шикваи Эрон аз мушкилоти ташкили TV-и форсизабонон [Iran skarży się na problemy z tworzeniem perskojęzycznej telewizji], [www 12].

53 Ibidem.
} 
GAJDA, Polityka językowa oraz kulturalna Islamskiej Republiki Iranu... 25

\section{Podsumowanie}

Kulturowe relacje Iranu z Tadżykistanem i Afganistanem pozostają poprawne mimo licznych nieporozumień zaistniałych wokół projektu mającego na celu zacieśnianie współpracy. Władze Iranu, jako dążące do ideologicznej i politycznej ekspansji w swym otoczeniu, nadal starają się wykorzystywać potencjał podobieństw języka i kultury, łączących obecny Iran z ziemiami wielkich imperiów z przeszłości. Polityka kulturalna i językowa Iranu w regionie jest zatem ważnym i skutecznym narzędziem budowania strefy wpływów, choć uwarunkowania międzynarodowe zaistniałe w ostatnich latach mocno ograniczają możliwość jej implementacji. Dużą przeszkodą na drodze do zacieśniania współpracy regionalnej pozostaje amerykańskie i rosyjskie zaangażowanie w tym kluczowym regionie. Innym uwarunkowaniem, które należy wskazać w podsumowaniu, jest czynnik religijny i fakt, że Iran jako państwo współrządzone przez szyicki kler (z dominującą rolą tegoż) wciąż wzbudza chęć zdystansowania się odeń w państwach większościowo sunnickich. Na ten obraz nakłada się dodatkowo szereg niewymienionych w tym artykule problemów granicznych afgańsko-irańskich, wśród których wskazać należy kontrowersje związane z pobytem nielegalnych imigrantów z Afganistanu w Iranie, przemyt afgańskiego opium przez terytorium irańskie, spór o zagospodarowanie wód rzeki Helmand i inne kwestie. Nie zmienia to jednak faktu, że poczucie bliskości kulturowej i językowej istnieje w świadomości zarówno władz, jak i społeczeństw Iranu, Afganistanu i Tadżykistanu, co w innych, bardziej sprzyjających okolicznościach, może zapewnić rozwój projektom takim, jak Unia Państw Perskojęzycznych i stacja telewizyjna Nawrooz TV. 
GAJDA, Polityka językowa oraz kulturalna Islamskiej Republiki Iranu... 26

\section{Bibliografia}

1. Adinabay E., Changing Media and Politics in Tajikistan, University of Oxford 2013, [www 14].

2. Awady A., Saudi Arabia, Iran and the Conflict in Afghanistan [w:] Fundamentalism Reborn? Afghanistan and the Taliban, W. Maley, London 2001.

3. BAHMAN-QADŻAR M. A., ايران و افغانستان از يخانكى تا تعيين مرزهاى سياسى Iran wa Afqanestan: Az jeganegi ta ta'jin-e marzha-je sijasi [Iran i Afganistan: Od jedności do ustalenia granic politycznych], Tehran 1384AP/2005.

4. BAIley H. W., Arya [w:] Encyclopaedia Iranica Online, [www 15].

5. Cummings M. C., Cultural Diplomacy and the United States Government: A Survey, Center for Arts and Culture, 2003.

6. Dawlat R., Szykwai Eron az muszkiloti taszkili TV-i forsizabonon Шикваи Эрон аз мушкилоти ташкили TV-и форсизабонон [Iran skar$\dot{z} y$ się na problemy $z$ tworzeniem perskojęzycznej telewizji], [www 12].

7. Dobbins J., Negotiating with Iran: Reflections from Personal Experience, "The Washington Quarterly”, 12/2010.

8. Gajda J., Afganistan - Iran - Tadżykistan. Relacje państw perskojęzycznych w 2010 roku [w:] Wschód i Zachód. Tolerancja i różnorodność, M. Woźniak, K. Zdulski (red.), Łódź 2013, s. 79-86.

9. Gajda S., Promocja języka i kultury polskiej a procesy uniwersalizacji $i$ nacjonalizacji kulturowo-językowej w świecie [w:] Promocja języka $i$ kultury polskiej wświecie, J. Mazur (red.), Lublin 1998.

10. General Assembly Recognizes 21 March as International Day of Nowruz, [Www 11].

11. Hiro D., Iran: The Geopolitics of the Islamic Revolution [w:] Inside Central Asia. A Political and Cultural History of Uzbekistan, Turkmenistan, Kazakhstan, Kyrgyzstan, Tajikistan, Turkey and Iran, New York 2009.

12. Hodgson M., The Venture of Islam. Conscience and History of a World Civilization (vol. II), Chicago 1974.

13. Iran Forges Closer Ties with Tajikistan, eurasianet.org, 24.01.2006, [www o9].

14. Iran, Afghanistan Underline Expansion of All-Out Ties, Fars News, 21.03.2016, [www 03].

15. Islamic Awakening Modeled on Iran Revolution, Press TV, 11.02.2012, [www 04]. 
GAJDA, Polityka językowa oraz kulturalna Islamskiej Republiki Iranu... 27

16. Johnston W., Iran's Cultural Foreign Policy in Southern Asia and the Southern Caucasus since 1991, „Central Asia and the Caucasus”, 46, 4/2007.

17. KDAM: Dar Surija taqiban 300 nafar szarwandoni Todżikeston medżangand [W Syrii walczy trzystu obywateli Tadżkistanu], ASIA-Plus, 22.11.2014, [Www 13].

18. Krasnowolska A., Historia Iranu, Wrocław 2010.

19. Marat E., Imagined Past, Uncertained Future - the Creation of National Ideologies in Kyrgyzstan and Tajikistan [w:] Problems of Post-comunism, Vol. 55, 1/2008.

20. Medrea S., Persian-Speaking Union created by Afghanistan, Iran, Tajikistan, [www 01].

21. Momin M., SArvinozi S. R., Af-Taj 2013: Sound, lights, inaction!, Afghanistan-Today.org, 8.11.2013, [www 08].

22. Muhatir A., Afghanistan and Tadjikistan: Destablishing Factors for South and Central Asian Region, "Journal of International Affairs", 3, 1/1998.

23. NiAyesh U., Deputy Minister: Iran welcomes Persian-speaking countries' union, Trend.az, 25.12.2013, [www 07].

24. Niechcią P., Tożsamość narodowa po tadżycku: Odtwarzanie koncepcji narodu $i$ jego historii w przestrzeni publicznej Republiki Tadżykistanu, „Przegląd Orientalistyczny”, 1-2/2016, s. 169-182.

25. Perry J., Folklore of the Iranian Region, „Asian Folklore Studies”, 60, 2001.

26. De Planhol X., Iran: i. Lands of Iran [w:] Encyclopaedia Iranica Online, [www 10].

27. President Rouhani urges expansion of ties among Persian-speaking countries, IRNA, 02.09.2013, [www 06].

28. Rachmonow E., Tadżycy w zwierciadle historii [w:] Tadżykistan - historia, społeczeństwo, polityka, T. Bodio (red.), Warszawa 2002.

29. Rouhani congratulates regional Leaders on Nouruz, Mehr News Agency, 21.03.2015, [www 02].

30. SaIKal A., Modern Afghanistan: A History of Struggle and Survival, London-New York 2004.

31. Schmitt R., Aryans [w:] Encyclopaedia Iranica Online, [www 16].

32. Skıadankowa M., Zrozumieć Iran, Warszawa 1996. 
GAJDA, Polityka językowa oraz kulturalna Islamskiej Republiki Iranu... 28

33. Tajikistan and Iran: Is Dushanbe Distancing Itself from Cultural Cousin?, eurasianet.org, 07.03.2011, [www 05].

34. Todżikon dar Qalamrawi Orijono [Tadżycy na terytorium Ariany], M. Szukurzoda (red.), Duszanbe 2009.

35. Yarshater E., Persia or Iran, „Iranian Studies” 22, 1/1989.

\section{Wykorzystane źródła internetowe:}

[www 01] http://www.cacianalyst.org/?q=node/4832 (dostęp: 14.12.2016) [www 02] http://en.mehrnews.com/news/115318/Rouhani-congratulatesregional-leaders-on-Nowruz (dostęp: 18.12.2016) [www 03] http://en.farsnews.com/newstext.aspx?nn=13950102000035 (dostęp: 18.12.2016)

[www 04] http://www.presstv.com/detail/226172.html (dostęp: 17.12.2016)

[www 05] http://www.eurasianet.org/node/63021 (dostęp: 15.12.2016) [www 06] http://en.irna.ir/News.aspx?Nid=2736193 (dostęp: 14.12.2016) [www 07] http://en.trend.az/iran/2225157.html (dostęp: 14.12.2014) [www 08] http://www.afghanistan-today.org/en/articles/6o/552/ (dostęp: 14.12.2016)

[www 09] http://www.eurasianet.org/departments/insight/articles/ eav012506.shtml (dostęp: 26.02.2017)

[www 10] http://www.iranicaonline.org/articles/iran-i-lands-of-iran (dostęp: 29.01.2017)

[www 11] http://www.un.org/News/Press/docs/2010/ga10916.doc.htm (dostęp: 22.05.2016)

[www 12] http://www.ozodi.org/a/24180142.html (dostęp: 4.02.2017)

[www 13] http://news.tj/tj/news/tajikistan/security/20141122/kdam-darsuriya-ta-iban-30o-nafar-sha-rvandoni-ikiston-me-angand (dostęp: 3.02.2017) [www 14] https://reutersinstitute.politics.ox.ac.uk/sites/default/files/ Changing\%2omedia\%2oand\%2opolitics\%2oin\%2oTajikistan.pdf (dostęp: 26.02.2017)

[www 15] http://www.iranicaonline.org/articles/arya-an-ethnic-epithet (dostęp: 7.04.2017)

[www 16] http://www.iranicaonline.org/articles/aryans (dostęp: 7.04.2017) 
GAJDA, Polityka językowa oraz kulturalna Islamskiej Republiki Iranu... 29

\title{
Abstract, keywords, about the author
}

\begin{abstract}
The cultural and linguistic policy of the Islamic Republic of Iran towards Afghanistan and Tajikistan

Afghanistan, Iran and Tajikistan share twenty five centuries of political history, although nowadays they retain three distinct national identities. All their roots are related to Iranian religions such as Zoroastrianism as well as Persian literature, poetry and the Iranian culture of the Achaemenian empires and their successors. Nowadays, the official languages of these countries remain closely related to one another. Iran has attempted to boost its influence in the regions of Middle East, South and Central Asia and seeks to use its cultural and linguistic affinity to forge relations with other Persian-speaking countries. This factor is no less important than the religious aspect - Shia Islam, which is considered to have been the most important determinant of Iran's foreign policy since 1979. The International Celebrations of Nouruz played a very important role in the process of integration.. The Iranian New Year, for some time has even become an occasion for trilateral meetings between the leaders of the countries engaged in the Persian Speaking Union project. However, over the last few years the integration process has slowed down. Despite many similarities, the cultures of Iran, Afghanistan and Tajikistan are also different. The same can be said about the directions of foreign policies of these countries. Despite these facts, the shared cultural heritage and its usage by Iran is surely a topic worthy of inclusion in the discourse on the contemporary Iranian world.
\end{abstract}

Keywords: Iran, Afghanistan, Tajikistan, politics, culture, language

Jakub G. GAJDA MA, a graduate in Iranian Studies from the Jagiellonian University, a $\mathrm{PhD}$ candidate of the Interdisciplinary Doctoral Program in the Humanities University of Łódź, an expert in Iran, Afghatnistan, Middle East and the Central Asia of the Amicus Europae Foundation and the Casimir Pulaski Foundation.

E-MAIL: jakubgajda@wp.pl 